\title{
D-Bifunctional Protein Deficiency
}

National Cancer Institute

\section{Source}

National Cancer Institute. D-Bifunctional Protein Deficiency. NCI Thesaurus. Code

C119676.

A rare, autosomal recessive inherited disorder caused by mutation in the HSD17B4 gene.

It is characterized by neurodegeneration that begins in infancy, hypotonia, and seizures.

The majority of the affected individuals lack developmental skills. 